\title{
The Known Antimammalian and Insecticidal Alkaloids Are Not Responsible for the Antifungal Activity of Epichlö̈ Endophytes
}

\author{
Krishni Fernando ${ }^{1,2}$, Priyanka Reddy ${ }^{1}$, Simone Vassiliadis ${ }^{1}$, German C. Spangenberg ${ }^{1,2}$, Simone J. Rochfort ${ }^{1,2}$ (1) \\ and Kathryn M. Guthridge ${ }^{1, *}$ \\ 1 Agriculture Victoria, AgriBio, Centre for AgriBioscience, Bundoora, Melbourne, VIC 3083, Australia; \\ krishni.fernando@agriculture.vic.gov.au (K.F.); priyanka.reddy@agriculture.vic.gov.au (P.R.); \\ simone.vassiliadis@agriculture.vic.gov.au (S.V.); german.spangenberg@agriculture.vic.gov.au (G.C.S.); \\ simone.rochfort@agriculture.vic.gov.au (S.J.R.) \\ 2 School of Applied Systems Biology, La Trobe University, Bundoora, Melbourne, VIC 3083, Australia \\ * Correspondence: kathryn.guthridge@agriculture.vic.gov.au
}

\section{check for}

updates

Citation: Fernando, K.; Reddy, P.; Vassiliadis, S.; Spangenberg, G.C.; Rochfort, S.J.; Guthridge, K.M. The Known Antimammalian and Insecticidal Alkaloids Are Not Responsible for the Antifungal Activity of Epichloë Endophytes. Plants 2021, 10, 2486. https:// doi.org/10.3390/plants10112486

Academic Editors: Oscar Santamaria and Sara Rodrigo

Received: 18 October 2021

Accepted: 13 November 2021

Published: 17 November 2021

Publisher's Note: MDPI stays neutral with regard to jurisdictional claims in published maps and institutional affiliations.

Copyright: (c) 2021 by the authors. Licensee MDPI, Basel, Switzerland. This article is an open access article distributed under the terms and conditions of the Creative Commons Attribution (CC BY) license (https:/ / creativecommons.org/licenses/by/ $4.0 /)$.

\begin{abstract}
Asexual Epichloë sp. endophytes in association with pasture grasses produce agronomically important alkaloids (e.g., lolitrem B, epoxy-janthitrems, ergovaline, peramine, and lolines) that exhibit toxicity to grazing mammals and/or insect pests. Novel strains are primarily characterised for the presence of these compounds to ensure they are beneficial in an agronomical setting. Previous work identified endophyte strains that exhibit enhanced antifungal activity, which have the potential to improve pasture and turf quality as well as animal welfare through phytopathogen disease control. The contribution of endophyte-derived alkaloids to improving pasture and turf grass disease resistance has not been closely examined. To assess antifungal bioactivity, nine Epichloë related compounds, namely peramine hemisulfate, $n$-formylloline-d3, $n$-acetylloline hydrochloride, lolitrem B, janthitrem A, paxilline, terpendole $\mathrm{E}$, terpendole $\mathrm{C}$, and ergovaline, and four Claviceps purpurea ergot alkaloids, namely ergotamine, ergocornine, ergocryptine, and ergotaminine, were tested at concentrations higher than observed in planta in glasshouse and field settings using in vitro agar well diffusion assays against three common pasture and turf phytopathogens, namely Ceratobasidium sp., Drechslera sp., and Fusarium sp. Visual characterisation of bioactivity using pathogen growth area, mycelial density, and direction of growth indicated no inhibition of pathogen growth. This was confirmed by statistical analysis. The compounds responsible for antifungal bioactivity of Epichloë endophytes hence remain unknown and require further investigation.
\end{abstract}

Keywords: Epichloë sp. endophytes; pasture protection; turf; disease control; alkaloids; antifungal activity; bioprotection

\section{Introduction}

Asexual Epichloë sp. are endophytic fungi that play a critical role in pastoral agricultural systems as they enhance pasture performance. Improved growth in pastures is achieved in part from the bioprotective properties endophytes confer, including pest and disease resistance as well as abiotic stress tolerance [1-4]. While the impact of alkaloids on animal performance and insect control is well understood [5-8], the bioprotective compounds responsible for improved pasture quality and performance, in particular disease control, have not been thoroughly investigated.

Pasture and turf grasses are threatened by many phytopathogens, including fungi, bacteria, and viruses. Severe disease outbreaks impact pasture quality and yield [9-11]. Adding to the effect on the dairy and meat industries by reduced yields, mycotoxins produced by some phytopathogenic fungi are a health threat to grazing mammals [12-14]. Better understanding of Epichloë-mediated disease resistance, and identifying the compounds responsible, provides an opportunity to identify Epichloë endophyte strains better suited for pastoral agriculture and turf systems. 
Epichloë sp. are able to improve disease resistance of host grasses by reducing pathogen incidence and/or disease severity [3,15-17]. Historically, the potential to improve disease resistance in pastures using endophytes has been investigated in vitro. This was achieved by assessing antifungal activity of different strains of Epichloë sp. against phytopathogens in dual culture, detached leaf, and spore germination assays $[1,3,18-20]$. The in vitro assays confirm the activity against a range of phytopathogens, e.g., Alternaria alternata, Bipolaris sorokiniana, Colletotrichum graminicola, Drechslera erythrospila, Ceratotobasidium cereale (Rhizoctonia cerealis), Rhizoctonia zeae, and Fusarium sp. [3,20,21]. There are also examples where endophyte control of biotrophic fungi, such as Puccinia coronata (crown rust), are evaluated $[19,22]$. Other studies evaluated in vitro culture filtrates and culture extracts of Epichloë sp. endophyte strains $[20,21]$. In these studies, the potential for antifungal compound production by Epichloë sp. endophytes was assessed with use of agar well diffusion assays and thin layer chromatography (TLC) bioautography assays $[20,21,23]$.

While the asexual (non-pathogenic) Epichloë sp. utilised in pasture and turf grasses have not been investigated with the same level of detail, bioactive antifungal compounds have been identified and isolated from sexual (pathogenic) Epichloë sp. Antifungal compounds that have been identified and isolated from Epichloë typhina include chokols (A-G), gamahonolide A, gamahonolide B, gamahorin, and epichlicin [24-27]. Several studies also describe isolation of antifungal agents from Epichloë festucae. An antifungal protein ( 55 amino acids, $6.3 \mathrm{kDa}$ ) named Efe-AfpA was isolated from E. festucae (Rose City isolate) and was shown to inhibit the growth of Sclerotinia homoeocarpa in a plate assay. Another antibiotic protein, VibA, was identified when the gene was overexpressed in E. festucae strain E437. The authors determined the VibA gene encoded for a biosynthetic enzyme that produced $\varepsilon$-poly-L-lysines of 28-34 lysine subunits. The antibiotic metabolites indole-3acetic acid, indole-3-ethanol, methylindole-3-carboxylate, indole-3-carboxaldehyde, $N, N$ diacetamide, cyclonerodiol (an isomer of chokol C) have been isolated from E. festucae (BM7, M. D. Richardson) and showed inhibition against Cryphonectria parasitica, Magnaporthe poae, Laetisaria fuciformis, and Rhizoctonia solani [17,21,28,29].

Fernando et al. (2020) previously identified variation for antifungal activity between different strains of asexual Epichloë sp. isolated from perennial ryegrass (Lolium perenne) and tall fescue (Festuca arundinacea) plants [20,30,31]. The study showed that unique compounds produced by three highly bioactive endophyte strains, namely SE, NEA12, and NEA23, may be associated with the distinct antifungal activity exhibited by each strain. In addition to the still-to-be isolated and characterised unique compounds, these strains have been assessed for in planta production of alkaloids including lolitrem B, ergovaline, peramine, $n$-acetylloline, $n$-formylloline and epoxy janthitrems. These alkaloids are usually only considered in their role as mammalian or insect toxins. However, there is a possibility that these alkaloids contribute to the observed antifungal activity.

Only one study, in 1991, has tested Epichloë sp. derived alkaloids for their antifungal potential. Seigel and Latch used disk diffusion assays to evaluate $n$-formylloline, $n$-acetylloline, peramine sulfate, ergonovine maleate, ergotamine tartrate, and ergocryptine (100 mg/disk) for bioactivity against the phytopathogens Ceratobasidium cereale, Colletotrichum graminicola, Rhizoctonia zeae, and Limonomyces roseipellis, and in each instance they did not observe bioactivity despite the high concentrations of each compound used in the assay [18].

While the study revealed no significant antifungal activity from these compounds it does not account for three major alkaloids, ergovaline, lolitrem B and epoxy-janthitrem I or indole diterpene biosynthetic intermediates paxilline, terpendole $\mathrm{E}$, and terpendole $\mathrm{C}$. In the last decade, epoxy-janthitrems, a class of indole diterpenes that are structurally related to lolitrem B, were identified in Epichloë sp. endophyte strains including NEA12. Due to the inherent instability of pure epoxy janthitrems, stable isolation and purification remain elusive [32]. Consequently, there are limited reports on their sound biological activity in insects and mammals [33]. Since the study in 1991, other relevant purified compounds 
have also become available, thus providing an opportunity to screen and quantify a wider range of compounds for their bioprotective properties.

This study analyses the antifungal activity of thirteen Epichloë sp. related compounds against the phytopathogens Ceratobasidium sp., Fusarium sp., and Drechslera sp. to determine their contribution to the observed bioactivity previously described in Epichloë sp. endophyte strains by Fernando et al. (2020) [20].

\section{Results}

Bioprotective alkaloids known to be produced by Epichloë sp. strains utilised in pastures and turf were obtained from either commercial or in-house sources to assess their antifungal activity toward three phytopathogens Ceratobasidium sp., Drechslera sp., and Fusarium sp. (Table 1) in an agar well diffusion assay. Concentrations well above those observed in planta were prepared for each compound to provide the best prospects of detecting antifungal activity (Table 2). The agar well diffusion assay results provide a visual representation of biological activity exhibited by these alkaloids. Antifungal activity is indicated by changes in the pathogen growth area, mycelial density, and direction of growth [20]. Image analysis using ImageJ software enables quantification of the activity by accurately measuring the pathogen growth area. The growth area measurements can then be used for statistical analysis.

Visual examination of agar well diffusion assays (Figure 1) suggest there is no effect on the growth of the three pathogens Ceratobasidium sp., Drechslera sp., and Fusarium sp., with no changes in growth area, mycelial density, or direction of growth, in the presence of any of the tested alkaloids.

The average pathogen growth area obtained from image data analysis was used as a measurable indication of antifungal activity (Figure 2). One-way ANOVA of day six observations confirmed that the tested Epichloë sp. alkaloids did not significantly reduce pathogen growth compared to the negative controls. The following Tukey pairwise comparison $p$ values, where $p<0.01$ is significantly different, are for Ceratobasidium sp., Drechslera sp., and Fusarium sp., respectively, when compared to the corresponding negative control: peramine hemisulfate $(p=1, p=1, p=0.999), n$-formylloline.d3 $(p=1, p=1$, $p=0.843), n$-acetylloline. $\mathrm{HCl}(p=0.939, p=1, p=0.997)$, lolitrem B $(p=1, p=1, p=1)$, janthitrem $\mathrm{A}(p=1, p=1, p=1)$, paxilline $(p=1, p=1, p=1)$, terpendole $\mathrm{E}(p=1, p=1$, $p=1)$, terpendole $C(p=1, p=1, p=0.997)$, ergovaline $(p=1, p=1, p=1)$, ergotamine $(p=1, p=1, p=1)$, ergocornine $(p=1, p=1, p=1)$, ergocryptine $(p=1, p=0.932, p=1)$, and ergotaminine ( $p=1, p=1, p=1)$. Carbendazim (1000 ppm; parts per million), a systemic benzimidazole fungicide commonly used in laboratory assays and in this study as a positive control, strongly inhibited the growth of the three pathogens Ceratobasidium sp. $(p<0.001)$, Drechslera sp. $(p<0.001)$, and Fusarium sp. $(p<0.001)$ by significantly reducing growth area, $(p<0.01)$. Strong growth inhibition of Ceratobasidium sp. and Fusarium sp. was observed as early as the third day, while Drechslera sp. was moderately inhibited at day six. The negative controls of $80 \%$ methanol, $1 \%$ lactic acid, $16 \%$ hydrochloric acid, and sterile distilled water showed no signs of pathogen inhibition. These data confirmed that the Epichloë sp. alkaloids tested do not show antifungal activity against the three grass pathogens Ceratobasidium sp., Drechslera sp., and Fusarium sp. 


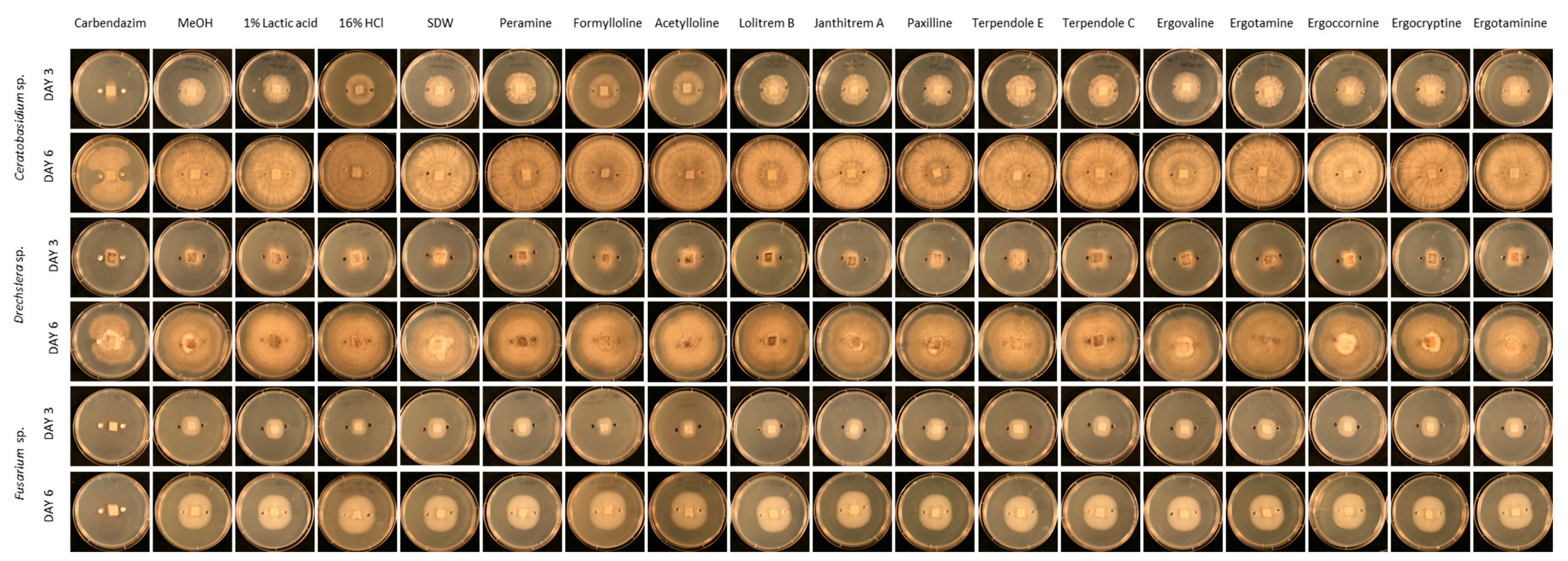

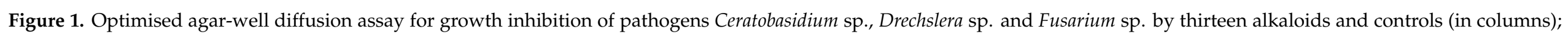

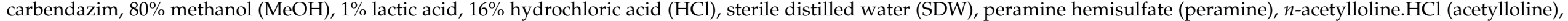

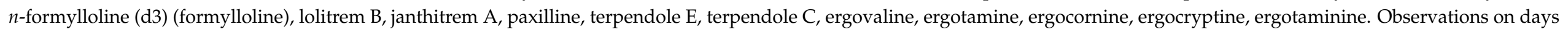
three and six (in rows) of the bioassay images are typical representatives of the five replicates. 
(a) Ceratobasidium sp.

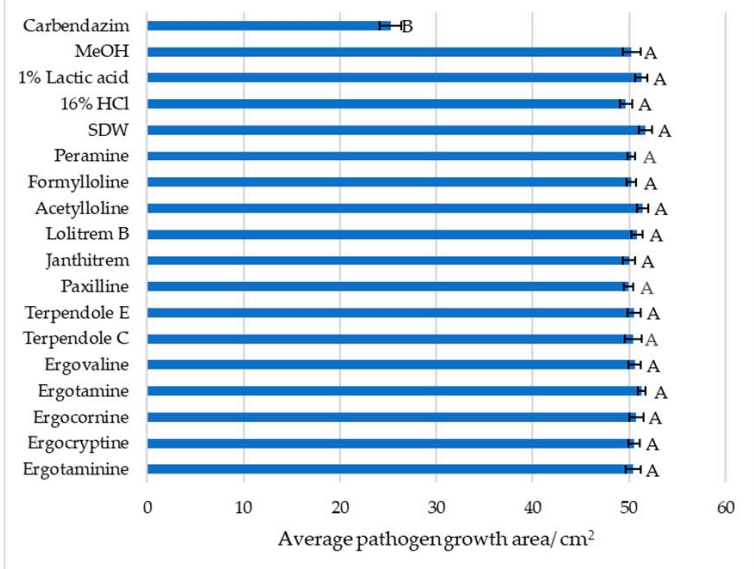

(b) Drechslera sp.

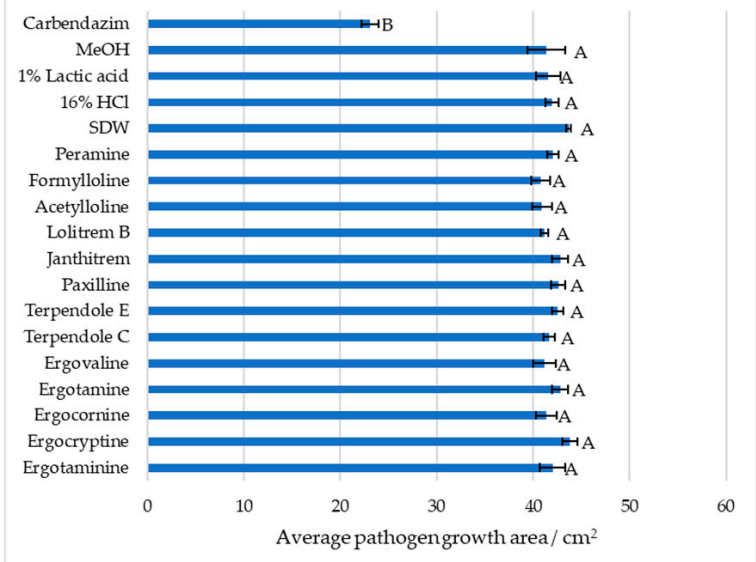

(c) Fusarium sp.

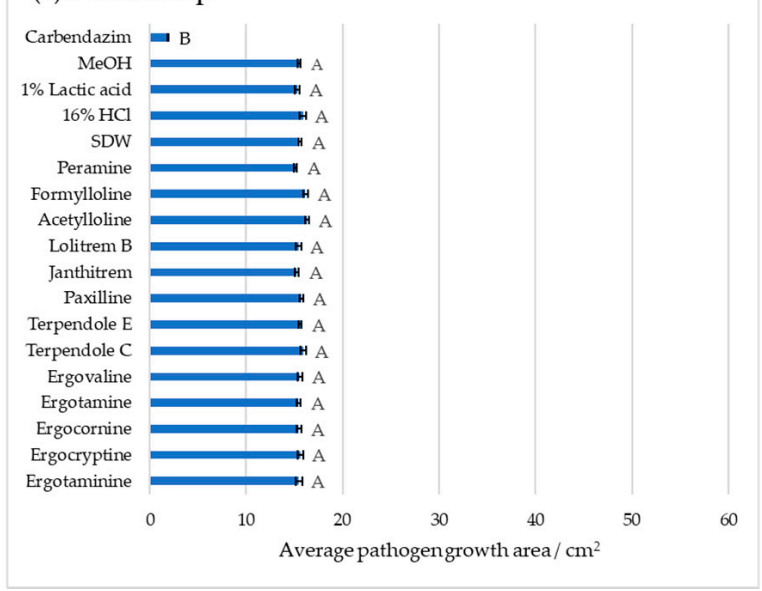

Figure 2. Pathogen growth inhibition by thirteen Epichloë sp. alkaloids and controls; carbendazim, $80 \%$ methanol $(\mathrm{MeOH}), 1 \%$ lactic acid, 16\% hydrochloric acid $(\mathrm{HCl})$, sterile distilled water (SDW), peramine hemisulfate (peramine), $n$-acetylloline. $\mathrm{HCl}$ (acetylloline), $n$-formylloline (d3) (formylloline), lolitrem B, janthitrem A, paxilline, terpendole E, terpendole C, ergovaline, ergotamine, ergocornine, ergocryptine, ergotaminine against (a) Ceratobasidium sp.; (b) Drechslera sp.; (c) Fusarium sp. Image analysis measured the growth area $\left(\mathrm{cm}^{2}\right)$ of the pathogen in the agar well diffusion assay at day six. All data are mean \pm standard error, $n=5$. Significance was determined by one-way ANOVA and Tukey post-hoc test for pairwise comparison; $p<0.01$ indicates significant inhibition. Means that do not share a letter are significantly different. In each instance Tukey post-hoc tests grouped the positive control, carbendazim, separately to all other treatment groups. 


\section{Discussion}

The antifungal activity of thirteen Epichloë sp. related alkaloids and intermediates from different compound classes (indole diterpenes, lolines, ergot alkaloids, and the pyrrolopyrazine alkaloid peramine) was assessed against three phytopathogenic fungi using in vitro agar well diffusion assays. No visible changes in pathogen growth were observed and image analysis confirmed there was no statistical difference between the growth areas of the pathogens in the presence of the pure compounds, namely peramine hemisulfate, $n$-formylloline-d3 ( $>98 \%$ pure), $n$-acetylloline hydrochloride $(>98 \%)$, lolitrem B $(>98 \%)$, janthitrem A $(>95 \%)$, paxilline $(>98 \%)$, terpendole E $(>95 \%)$, terpendole C $(>95 \%)$, ergovaline ( $\geq 97 \%)$, ergotamine $(\geq 97 \%)$, ergocornine $(>98 \%)$, ergocryptine $(>98 \%)$, and ergotaminine $(>98 \%)$, when compared to negative controls. This confirmed that these compounds do not possess antifungal activity at the concentrations tested against Ceratobasidium sp., Drechslera sp., or Fusarium sp. In contrast, the positive control Carbendazim, a fungicide commonly used in laboratory assays [34,35], strongly inhibited the growth of the three pathogens.

Visual observations from this study confirm previous findings by Siegel and Latch (1991) [18], and statistical analysis of quantified image data corroborates the findings. This study also further extends the observations made by Siegel and Latch (1991), to include Epichloë sp. (and related) alkaloids and pathway intermediates not previously investigated, such as ergovaline, ergocornine, ergotaminine, lolitrem B, janthitrem A, paxilline, terpendole $\mathrm{E}$, and terpendole $\mathrm{C}$.

The purity of the tested compounds, as described above, was greater than $95 \%$. Each of the compounds used in this study have been shown to be in bioactive forms in other studies. For example, ergovaline, ergotamine, lolitrem $B$, paxilline, terpendole $C$, and terpendole $E$ used in this study were previously used in investigations of mammalian toxicity in mice by Reddy et al. $[6,36,37]$. Paxilline and janthitrem A were used to investigate toxicity in mouse and insect models [32,38]. Ergot alkaloids ergotamine, ergocornine, ergocryptine, and ergotaminine have been widely used in investigations of mammalian toxicity [39]. Ergotamine, ergocornine, and ergocryptine are also known for their therapeutic application in medical conditions, e.g., migraine, uterotonics, cancer treatments, type II diabetes, and Parkinson's disease [40]. In instances where deuterated or salt derivatives of the compounds were used, the compounds may not display the same properties as in their natural forms. However, in the case of peramine hemisulfate, $n$-formylloline- $\mathrm{d} 3$, and $n$-acetylloline hydrochloride, the salts dissociate in solution to their natural forms, which are known for their insecticidal activity [41-43]. The salts and solvents were also pre-tested for their effects on pathogen growth in agar well diffusion assays, and $80 \%$ methanol, $16 \%$ $\mathrm{HCl}$, and $1 \%$ lactic acid were included in the bioassay as negative controls.

The concentrations of the test alkaloids used in this study also provide an accurate indication of the likely occurrence of bioprotection conferred by individual compounds under natural conditions. To make an informed choice for the concentrations tested, average in planta concentrations were obtained from glasshouse-maintained perennial ryegrass-endophyte symbiota using liquid chromatography-mass spectrometry (LCMS) based detection and analysis of Epichloë sp. endophyte alkaloids [44]. It is important to note that alkaloid concentration varies enormously under different field conditions, such as season, temperature, and local environment [45,46], as well as during host plant establishment and development [47]. There is also significant host plant genotype-endophyte strain interaction that impacts quantitative alkaloid concentrations [45,46]. In this study, we analyzed average alkaloid abundance in planta for selected perennial ryegrass-endophyte symbiota, i.e., NEA12 (epoxy janthitrem I), NEA23 (lolines), and SE (peramine, lolitrem B, paxilline, terpendole $\mathrm{E}$, terpendole $\mathrm{C}$ and ergovaline), grown under controlled glasshouse conditions. This was to inform the concentrations used in the bioassay as the abundance of some of these alkaloids produced in the field, particularly indole diterpene pathway intermediates and lolines in perennial ryegrass, has not been published. However, alkaloid abundances of well characterized endophyte-derived alkaloids, such as lolitrem B, ergova- 
line, and peramine, are higher in the glasshouse-maintained plants measured in this study than what is generally observed in the field $[48,49]$.

While perennial ryegrass infected with Epichloë sp. endophytes provides protection against insect pests and diseases and thus is beneficial to pastoral agricultural systems, some of the major alkaloids are also detrimental to grazing animals at concentrations that result in toxicity (i.e., lolitrem B, paxilline, terpendole C, epoxy-janthitrem I, ergovaline). These alkaloids would not be suitable as biocontrol agents at toxic concentrations $[5,6]$. Hence, while it is possible that at higher concentrations the alkaloids would display some antifungal activity, they would be neither safe nor biologically relevant.

In a previous study by Fernando et al. (2020) [20], bioactive Epichloë sp. endophyte strains were identified in an in vitro screen for antifungal activity. A key observation was the differential bioactivity observed between three highly bioactive strains, namely NEA12, NEA23, and SE [20]. The three strains also exhibit different alkaloid profiles. NEA23 produces peramine, $n$-formylloline, and $n$-acetylloline, NEA12 produces epoxy janthitrems, and SE produces lolitrem B, peramine, and ergovaline $[30,31,50]$. This study establishes that the known, and well characterised in terms of animal and insect toxicity, endophyte-derived alkaloids are not responsible for the antifungal properties previously observed. It is now important to identify and characterise the compounds responsible for the antifungal activity of novel strains.

\section{Conclusions}

Epichloë sp. endophytes provide pasture and turf grasses with resistance to insect pests, animal herbivory, and disease resistance. For pastoral agriculture, the endophytes should maintain their insect and disease protection but contain little or none of the animal toxins that can cause disease in grazing animals. Although the compounds responsible for animal toxicity are largely known, the compounds responsible for disease resistance are not yet thoroughly described. In this study, the major alkaloids were tested for their in vitro antifungal activity. None of the tested compounds exhibited in vitro bioactivity towards the three phytopathogens tested. Since known alkaloid metabolites are not responsible for the antifungal activity expressed by Epichloë sp. endophyte strains, the bioactive metabolites are yet to be discovered. While this study provides an opportunity to rule out the contribution of alkaloids known to be produced by Epichloë endophyte strains, it opens avenues to explore novel metabolites produced by Epichloë endophytes.

\section{Materials and Methods}

\subsection{Plant Material}

All plant material was obtained from a glasshouse maintained (natural day lengths and a mean temperature of $22^{\circ} \mathrm{C}$ ) collection at Agriculture Victoria Research, Bundoora, Victoria, Australia.

\subsection{Plant Pathogens}

All pathogens (Table 1) were obtained from the National Collection of Fungi, Bundoora Herbarium, Victoria. Pathogens were stored as solid cultures on potato dextrose agar (PDA) plates $\left(90 \mathrm{~mm} \times 14 \mathrm{~mm}\right.$ ) (Sigma-Aldrich, Castle Hill, NSW, Australia) at $22{ }^{\circ} \mathrm{C}$ in the dark, and sub-cultured every two months to maintain stocks.

The genus of the pathogens used in this study was confirmed by internal transcribed spaces (ITS) sequence analysis described by Fernando et al. (2020) [20]. 
Table 1. Summary of pathogens selected for this study.

\begin{tabular}{|c|c|c|c|c|c|}
\hline Species & Host/Source & $\begin{array}{l}\text { Accession } \\
\text { Number }\end{array}$ & Disease & $\begin{array}{l}\text { Effect on Pasture/ } \\
\text { Seed Production }\end{array}$ & References \\
\hline Ceratobasidium sp. & $\begin{array}{l}\text { Triticum aestivum } \\
\text { (wheat) }\end{array}$ & VPRI 22537 & $\begin{array}{l}\text { yellow patch/ } \\
\text { sharp eyespot }\end{array}$ & Reduced yield & [51-53] \\
\hline Drechslera sp. & $\begin{array}{l}\text { Briza maxima } \\
\text { (rattle grass) }\end{array}$ & VPRI 12962 & $\begin{array}{l}\text { brown blight and } \\
\text { net blotch }\end{array}$ & $\begin{array}{c}\text { Dry matter and herbage } \\
\text { yield reduction }\end{array}$ & {$[10,54]$} \\
\hline Fusarium sp. & $\begin{array}{c}\text { Lolium perenne } \\
\text { (perennial ryegrass) }\end{array}$ & VPRI 43403 & Fusarium patch & $\begin{array}{l}\text { Reduced yield and dry } \\
\text { matter }\end{array}$ & [55] \\
\hline
\end{tabular}

\subsection{Chemicals}

Compounds were obtained from either commercial suppliers or isolated in-house as described in Table 2. In instances where an identical Epichloë related compound was not available, the deuterated, or salt derivative of the compound was examined. Stock solutions of compounds peramine hemisulfate, deuterated $n$-formylloline ( $n$-formylloline-d3), $n$-acetylloline hydrochloride, janthitrem $\mathrm{A}$, paxilline, terpendole $\mathrm{E}$, terpendole $\mathrm{C}$, ergocornine, ergocryptine, ergotaminine in 4:1 $(v / v)$ methanol: water $\left(\mathrm{H}_{2} \mathrm{O}\right)$ (Fisher chemicals, Fair Lawn, NJ, USA) following manufacturer's instruction. Ergovaline isolated from perennial ryegrass seeds by Reddy et al. [6] and ergotamine were pre-stored in a stock solution of $1 \%$ lactic acid (neat lactic acid, Sigma Aldrich, St. Louis, MO, USA, diluted with ultrapure distilled water, Invitrogen, Waltham, MA, USA). Lolitrem B isolated from perennial ryegrass seeds by Reddy et al. [56] was in 4:1 (v/v) methanol: $\mathrm{H}_{2} \mathrm{O}$ stock solution. All compounds were diluted to the desired concentrations (Table 2) in stock solution. For the positive control, a $1000 \mathrm{ppm}$ solution of antifungal compound carbendazim (methyl benzimidazol-2-ylcarbamate; 97\% pure; Sigma-Aldrich, Castle Hill, NSW, Australia), a systemic benzimidazole fungicide commonly used in both laboratory studies as well as in the field to control a broad range of diseases in crops [34,35,57,58], was prepared in 4:1 $(v / v)$ methanol: $\mathrm{H}_{2} \mathrm{O}, 1 \%$ lactic acid (neat lactic acid, Sigma Aldrich, diluted with ultrapure distilled water) and $16 \%$ hydrochloric acid $(\mathrm{HCl})(37 \% \mathrm{HCl}$, Scharlau Chemie S.A., Spain, diluted with ultrapure distilled water) was used [59].

Table 2. Purified compounds and concentrations used in bioassay.

\begin{tabular}{|c|c|c|c|c|c|}
\hline $\begin{array}{l}\text { Biosynthesis } \\
\text { Pathway }\end{array}$ & $\begin{array}{l}\text { Purified Compound } \\
\text { (Purity, \%) }\end{array}$ & $\begin{array}{l}\text { Chemical } \\
\text { Formula }\end{array}$ & $\begin{array}{l}\text { Concentration } \\
\text { Used in } \\
\text { Bioassay (ppm) }\end{array}$ & $\begin{array}{l}\text { Concentration in } \\
\text { Planta }{ }^{1,3}(\mathrm{ppm})\end{array}$ & Source \\
\hline Peramine & $\begin{array}{l}\text { Peramine } \\
\text { hemisulfate }\end{array}$ & $\mathrm{C}_{12} \mathrm{H}_{17} \mathrm{~N}_{5} \mathrm{O} \cdot \mathrm{H}_{2} \mathrm{SO}_{4}$ & 100 & $52.24 \pm 3.10$ & $\begin{array}{l}\text { Toronto Research } \\
\text { Chemicals, North York, } \\
\text { ON, Canada }\end{array}$ \\
\hline \multirow{2}{*}{ Loline } & $\begin{array}{l}n \text {-Formylloline-d3 } \\
(>98 \%)\end{array}$ & $\mathrm{C}_{9} \mathrm{H}_{11} \mathrm{D}_{3} \mathrm{~N}_{2} \mathrm{O}_{2}$ & 500 & $427.92 \pm 26.62$ & \multirow{2}{*}{$\begin{array}{l}\text { Toronto Research } \\
\text { Chemicals, North York, } \\
\text { ON, Canada } \\
\text { Toronto Research } \\
\text { Chemicals, North York, } \\
\text { ON, Canada }\end{array}$} \\
\hline & $\begin{array}{l}n \text {-Acetylloline. } \\
\text { Hydrochloride } \\
(>98 \%)\end{array}$ & $\mathrm{C}_{10} \mathrm{H}_{16} \mathrm{~N}_{2} \mathrm{O}_{2} \cdot \mathrm{HCl}$ & 250 & $\begin{array}{l}\text { typically trace } \\
\text { levels in perennial } \\
\text { ryegrass } 2\end{array}$ & \\
\hline \multirow{5}{*}{$\begin{array}{l}\text { Indole } \\
\text { diterpene }\end{array}$} & Lolitrem B (>98\%) & $\mathrm{C}_{42} \mathrm{H}_{55} \mathrm{NO}_{7}$ & 10 & $4.88 \pm 0.64$ & \multirow{2}{*}{$\begin{array}{l}\text { (Reddy et al., 2019) [56] } \\
\text { BioAustralis, Smithfield } \\
\text { NSW, Australia }\end{array}$} \\
\hline & Janthitrem A (>95\%) & $\mathrm{C}_{37} \mathrm{H}_{47} \mathrm{NO}_{6}$ & 50 & $11.86 \pm 0.85$ & \\
\hline & Paxilline (>98\%) & $\mathrm{C}_{27} \mathrm{H}_{33} \mathrm{NO}_{4}$ & 10 & $0.24 \pm 0.05$ & $\begin{array}{l}\text { Sigma-Aldrich, St. Louis, } \\
\text { MO, USA }\end{array}$ \\
\hline & Terpendole E (>95\%) & $\mathrm{C}_{28} \mathrm{H}_{39} \mathrm{NO}_{3}$ & 10 & $0.061 \pm 0.01$ & $\begin{array}{l}\text { Sigma-Aldrich, St. Louis, } \\
\text { MO, USA }\end{array}$ \\
\hline & Terpendole C (>95\%) & $\mathrm{C}_{32} \mathrm{H}_{41} \mathrm{NO}_{5}$ & 10 & $1.33 \pm 0.23$ & $\begin{array}{l}\text { Sigma-Aldrich, St. Louis, } \\
\text { MO, USA }\end{array}$ \\
\hline
\end{tabular}


Table 2. Cont.

\begin{tabular}{|c|c|c|c|c|c|}
\hline $\begin{array}{l}\text { Biosynthesis } \\
\text { Pathway }\end{array}$ & $\begin{array}{l}\text { Purified Compound } \\
\text { (Purity, \%) }\end{array}$ & $\begin{array}{l}\text { Chemical } \\
\text { Formula }\end{array}$ & $\begin{array}{l}\text { Concentration } \\
\text { Used in } \\
\text { Bioassay (ppm) }\end{array}$ & $\begin{array}{l}\text { Concentration in } \\
\text { Planta }{ }^{1,3}(\mathrm{ppm})\end{array}$ & Source \\
\hline \multirow{5}{*}{$\begin{array}{l}\text { Ergot } \\
\text { alkaloid }\end{array}$} & Ergovaline ( $\geq 97 \%)$ & $\mathrm{C}_{29} \mathrm{H}_{35} \mathrm{~N}_{5} \mathrm{O}_{5}$ & 10 & $0.40 \pm 0.08$ & \multirow{2}{*}{$\begin{array}{l}\text { (Reddy et al., 2020) [6] } \\
\text { LGC Standards, Wesel, } \\
\text { Germany }\end{array}$} \\
\hline & Ergotamine $(\geq 97 \%)$ & $\mathrm{C}_{33} \mathrm{H}_{35} \mathrm{~N}_{5} \mathrm{O}_{5}$ & 10 & NA & \\
\hline & Ergocornine (>98\%) & $\mathrm{C}_{31} \mathrm{H}_{39} \mathrm{~N}_{5} \mathrm{O}_{5}$ & 10 & NA & $\begin{array}{l}\text { LGC Standards, Wesel, } \\
\text { Germany }\end{array}$ \\
\hline & Ergocryptine (>98\%) & $\mathrm{C}_{32} \mathrm{H}_{41} \mathrm{~N}_{5} \mathrm{O}_{5}$ & 10 & NA & $\begin{array}{l}\text { LGC Standards, Wesel, } \\
\text { Germany }\end{array}$ \\
\hline & Ergotaminine (>98\%) & $\mathrm{C}_{33} \mathrm{H}_{35} \mathrm{~N}_{5} \mathrm{O}_{5}$ & 10 & NA & $\begin{array}{l}\text { LGC Standards, Wesel, } \\
\text { Germany }\end{array}$ \\
\hline
\end{tabular}

\begin{abstract}
${ }^{1}$ Average alkaloid concentrations \pm SEM in planta are from leaf material harvested from glasshouse maintained perennial ryegrassendophyte symbiota. Selected endophytes NEA12 (LpTG-3; epoxy janthitrem I, $n=114$ ), NEA23 (FaTG-3; lolines, $n=52$ ), and Standard Endophyte (SE; Epichloë festucae var. lolii; peramine, lolitrem B, paxilline, terpendole E, terpendole C and ergovaline, $n=40$ ); $\mathrm{NA}$, not applicable to Epichloë sp., these compounds are produced by Claviceps purpurea. ${ }^{2}$ Average concentrations of $n$-acetylloline in tall fescueNEA23 symbiota are $119.9 \pm 13.24(n=23)$. Concentrations are indicated as parts per million $(\mathrm{ppm}){ }^{3}$ Alkaloid concentrations observed in glasshouse-maintained plants in this study are higher than the maximum concentrations generally observed under field conditions.
\end{abstract}

\title{
5.4. Agar Well Diffusion Assay
}

Bioassays were conducted on PDA plates $(90 \mathrm{~mm} \times 14 \mathrm{~mm})$. A $4 \mathrm{~mm}$ cork borer was used to make two $4 \mathrm{~mm}$ diameter wells $2 \mathrm{~cm}$ apart. The bottoms of the wells were then sealed using $25 \mu \mathrm{L}$ of PDA media to ensure the compound was retained closer to the surface. A $5 \times 5 \mathrm{~mm}$ plug of pathogenic fungal mycelia was transferred onto the centre of the PDA media plate and each agar well was filled with $20 \mu \mathrm{L}$ of the compound solution. The bioassay plates were prepared in replicates $(n=5)$. Plates were incubated at $22{ }^{\circ} \mathrm{C}$ in the dark for eight days and observations were taken daily from day three. Two negative controls and one positive control were prepared. For the negative controls, the agar wells were filled with either $20 \mu \mathrm{L}$ of sterile distilled water or 4:1, $v / v$ methanol: $\mathrm{H}_{2} \mathrm{O}$ or $1 \%$ lactic acid or $16 \% \mathrm{HCl}$. Positive controls were prepared by filling the agar wells with $20 \mu \mathrm{L}$ of carbendazim [20]. Pathogen growth area $\left(\mathrm{cm}^{2}\right)$ was analysed using ImageJ $1 \times$ software (NIH, Bethesda, MA, USA). Image data of the sixth day of observations were used for the measurement of pathogen growth. One-way ANOVA was performed using Minitab $^{\circledR} 19$ Statistical Software (Minitab, LLC, State College, PA, USA). Tukey post hoc comparison tables at $99 \%$ confidence level were used to determine significant differences in antifungal activity.

Author Contributions: Conceptualization: K.F., P.R., K.M.G. and S.J.R.; methodology: K.F. and S.V.; data analysis, K.F.; writing-original draft preparation, K.F.; writing—editing and review: K.F., K.M.G., P.R., S.V., S.J.R. and G.C.S.; supervision and project administration: K.M.G., P.R., S.J.R. and G.C.S. All authors have read and agreed to the published version of the manuscript.

Funding: The research was funded by Agriculture Victoria and DairyBio.

Institutional Review Board Statement: Not applicable.

Informed Consent Statement: Not applicable.

Data Availability Statement: The data presented in this study are contained in the article.

Acknowledgments: The authors thank the following people for their contribution: Jacqueline Edwards for providing phytopathogen cultures from the National Collection of Fungi. Emma J. Ludlow and Inoka K. Hettiarachchige for endophyte diagnostics and providing endophyte positive plant samples for LCMS analysis.

Conflicts of Interest: The authors declare no conflict of interest. 


\section{References}

1. Christensen, M. Antifungal activity in grasses infected with Acremonium and Epichloë endophytes. Australas. Plant Pathol. 1996, 25, 186-191. [CrossRef]

2. Scott, B. Epichloë endophytes: Fungal symbionts of grasses. Curr. Opin. Microbiol. 2001, 4, 393-398. [CrossRef]

3. Tian, P.; Nan, Z.; Li, C.; Spangenberg, G. Effect of the endophyte Neotyphodium lolii on susceptibility and host physiological response of perennial ryegrass to fungal pathogens. Eur. J. Plant Pathol. 2008, 122, 593-602. [CrossRef]

4. Ruppert, K.G.; Matthew, C.; McKenzie, C.M.; Popay, A.J. Impact of Epichloë endophytes on adult Argentine stem weevil damage to perennial ryegrass seedlings. Entomol. Exp. Appl. 2017, 163, 328-337. [CrossRef]

5. Reddy, P.; Guthridge, K.; Vassiliadis, S.; Hemsworth, J.; Hettiarachchige, I.; Spangenberg, G.; Rochfort, S. Tremorgenic mycotoxins: Structure diversity and biological activity. Toxins 2019, 11, 302. [CrossRef]

6. Reddy, P.; Hemsworth, J.; Guthridge, K.M.; Vinh, A.; Vassiliadis, S.; Ezernieks, V.; Spangenberg, G.C.; Rochfort, S.J. Ergot alkaloid mycotoxins: Physiological effects, metabolism and distribution of the residual toxin in mice. Sci. Rep. 2020, 10, 9714. [CrossRef]

7. Bacon, C.W. Procedure for isolating the endophyte from tall fescue and screening isolates for ergot alkaloids. Appl. Environ. Microbiol. 1988, 54, 2615-2618. [CrossRef] [PubMed]

8. Gallagher, R.T.; Hawkes, A.D.; Steyn, P.S.; Vleggaar, R. Tremorgenic neurotoxins from perennial ryegrass causing ryegrass staggers disorder of livestock: Structure elucidation of lolitrem B. J. Chem. Soc. Chem. Commun. 1984, 9, 614-616. [CrossRef]

9. Xia, C.; Li, N.; Zhang, Y.; Li, C.; Zhang, X.; Nan, Z. Role of Epichloë endophytes in defense responses of cool-season grasses to pathogens: A review. Plant Dis. 2018, 102, 2061-2073. [CrossRef] [PubMed]

10. Latch, G. Fungous diseases of ryegrasses in New Zealand: I. Foliage diseases. N. Z. J. Agric. Res. 1966, 9, 394-409. [CrossRef]

11. Kolliker, R.; Kraehenbuehl, R.; Boller, B.; Widmer, F. Genetic diversity and pathogenicity of the grass pathogen Xanthomonas translucens pv. graminis. Syst. Appl. Microbiol. 2006, 29, 109-119. [CrossRef]

12. Smith, B.; Towers, N. Mycotoxicoses of grazing animals in New Zealand. N. Z. Vet. J. 2002, 50, 28-34. [CrossRef] [PubMed]

13. Di Menna, M.E.; Smith, B.L.; Miles, C.O. A history of facial eczema (pithomycotoxicosis) research. N. Z. J. Agric. Res. 2009, 52, 345-376. [CrossRef]

14. Tangni, E.K.; Pussemier, L.; Van Hove, F. Mycotoxin contaminating maize and grass silages for dairy cattle feeding: Current state and challenges. J. Anim. Sci. Adv. 2013, 3, 492-511.

15. Bacon, C.; Porter, J.; Robbins, J.; Luttrell, E. Epichloë typhina from toxic tall fescue grasses. Appl. Environ. Microbiol. 1977, 34, 576-581. [CrossRef]

16. Zhou, L.; Zhang, X.; Li, C.; Christensen, M.J.; Nan, Z. Antifungal activity and phytochemical investigation of the asexual endophyte of Epichloë sp. from Festuca sinensis. Sci. Chi. Life Sci. 2015, 58, 821-826. [CrossRef]

17. Niones, J.T.; Takemoto, D. An isolate of Epichloë festucae, an endophytic fungus of temperate grasses, has growth inhibitory activity against selected grass pathogens. J. Gen. Plant Pathol. 2014, 80, 337-347. [CrossRef]

18. Siegel, M.R.; Latch, G.C. Expression of antifungal activity in agar culture by isolates of grass endophytes. Mycologia 1991, 83, 529-537. [CrossRef]

19. Christensen, M.J.; Latch, G.C.M. Variation among isolates of Acremonium endophytes (A. coenophialum and possibly A. typhinum) from tall fescue (Festuca arundinacea). Mycol. Res. 1991, 95, 1123-1126. [CrossRef]

20. Fernando, K.; Reddy, P.; Hettiarachchige, I.K.; Spangenberg, G.C.; Rochfort, S.J.; Guthridge, K.M. Novel antifungal activity of Lolium-associated Epichloë endophytes. Microorganisms 2020, 8, 955. [CrossRef]

21. Yue, Q.; Miller, C.J.; White, J.F.; Richardson, M.D. Isolation and characterization of fungal inhibitors from Epichloë festucae. J. Agric. Food Chem. 2000, 48, 4687-4692. [CrossRef]

22. Pańka, D.; Jeske, M.; Troczyński, M. Effect of Neotyphodium uncinatum endophyte on meadow fescue yielding, health status and ergovaline production in host-plants. J. Plant Prot. Res. 2011, 51, 362-370. [CrossRef]

23. White, J.F.; Cole, G.T. Endophyte-host associations in forage grasses. IV. The endophyte of Festuca versuta. Mycologia 1986, 78, 102-107. [CrossRef]

24. Hiroyuki, K.; Satoshi, T.; Shun-ichi, T.; Yoshihara, T.; Sakamura, S.; Shimanuki, T.; Sato, T.; Tajimi, A. New fungitoxic sesquiterpenoids, chokols AG, from stromata of Epichloe typhina and the absolute configuration of chokol E. Agric. Biol. Chem. 1989, 53, 789-796. [CrossRef]

25. Koshino, H.; Yoshihara, T.; Ichihara, A.; Tajimi, A.; Shimanuki, T. Two sphingoid derivatives from stromata of Epichloë typhina on Phleum pratense. Phytochemistry 1992, 31, 3757-3759. [CrossRef]

26. Koshino, H.; Yoshihara, T.; Okuno, M.; Sakamura, S.; Tajimi, A.; Shimanuki, T. Gamahonolides A, B, and gamahorin, novel antifungal compounds from stromata of Epichloë typhina on Phleum pratense. Biosci. Biotechnol. Biochem. 1992, 56, 1096-1099. [CrossRef]

27. Seto, Y.; Takahashi, K.; Matsuura, H.; Kogami, Y.; Yada, H.; Yoshihara, T.; Nabeta, K. Novel cyclic peptide, epichlicin, from the endophytic fungus, Epichloe typhina. Biosci. Biotechnol. Biochem. 2007, 71, 1470-1475. [CrossRef]

28. Purev, E.; Kondo, T.; Takemoto, D.; Niones, J.T.; Ojika, M. Identification of $\varepsilon$-poly-l-lysine as an antimicrobial product from an Epichloë endophyte and isolation of fungal $\varepsilon$-PL synthetase gene. Molecules 2020, 25, 1032. [CrossRef]

29. Tian, Z.; Wang, R.; Ambrose, K.V.; Clarke, B.B.; Belanger, F.C. The Epichloë festucae antifungal protein has activity against the plant pathogen Sclerotinia homoeocarpa, the causal agent of dollar spot disease. Sci. Rep. 2017, 7, 5643. [CrossRef] 
30. Kaur, J.; Ekanayake, P.N.; Tian, P.; van Zijll de Jong, E.; Dobrowolski, M.P.; Rochfort, S.J.; Mann, R.C.; Smith, K.F.; Forster, J.W.; Guthridge, K.M.; et al. Discovery and characterisation of novel asexual Epichloë endophytes from perennial ryegrass (Lolium perenne L.). Crop. Past. Sci. 2015, 66, 1058. [CrossRef]

31. Ekanayake, P.N.; Kaur, J.; Tian, P.; Rochfort, S.J.; Guthridge, K.M.; Sawbridge, T.I.; Spangenberg, G.C.; Forster, J.W. Genomic and metabolic characterisation of alkaloid biosynthesis by asexual Epichloë fungal endophytes of tall fescue pasture grasses. Genome 2017, 60, 496-509. [CrossRef]

32. Babu, J.V.; Popay, A.J.; Miles, C.O.; Wilkins, A.L.; di Menna, M.E.; Finch, S.C. Identification and structure elucidation of janthitrems $\mathrm{A}$ and D from Penicillium janthinellum and determination of the tremorgenic and anti-insect activity of janthitrems A and B. J. Agric. Food Chem. 2018, 66, 13116-13125. [CrossRef] [PubMed]

33. Tapper, B.A.; Cooper, B.M.; Easton, H.S.; Fletcher, L.R.; Hume, D.E.; Lane, G.A.; Latch, G.C.M.; Pennell, C.G.L.; Popay, A.J.; Christensen, M.J. Grass Endophytes; World Intellectual Property Organization: Geneva, Switzerland, 2004; Available online: https:/ / patents.google.com/patent/WO2004106487A2/un (accessed on 12 November 2021).

34. Oliver, A.M.; Leathwick, D.M.; Waghorn, T.S.; Miller, C.M.; Atkinson, D.S. Carbendazim, at concentrations used on pasture for facial eczema control, reduces development of Trichostrongylus colubriformis when sprayed onto infected sheep faeces. N. Z. Vet. J. 2009, 57, 383-387. [CrossRef]

35. Al-Rahmah, A.; Mostafa, A.; Abdel-Megeed, A.; Yakout, S.; Hussein, S. Fungicidal activities of certain methanolic plant extracts against tomato phytopathogenic fungi. Afr. J. Microbiol. Res. 2013, 7, 517-524.

36. Reddy, P.; Rochfort, S.; Read, E.; Deseo, M.; Jaehne, E.; Van Den Buuse, M.; Guthridge, K.; Combs, M.; Spangenberg, G.; Quinn, J. Tremorgenic effects and functional metabolomics analysis of lolitrem B and its biosynthetic intermediates. Sci. Rep. 2019, 9, 9364. [CrossRef]

37. Reddy, P.; Vincent, D.; Hemsworth, J.; Ezernieks, V.; Guthridge, K.; Spangenberg, G.C.; Rochfort, S.J. Effects of ergotamine on the central nervous system using untargeted metabolomics analysis in a mouse model. Sci. Rep. 2021, 11, 19542. [CrossRef]

38. Finch, S.C.; Prinsep, M.R.; Popay, A.J.; Wilkins, A.L.; Webb, N.G.; Bhattarai, S.; Jensen, J.G.; Hawkes, A.D.; Babu, J.V.; Tapper, B.A.; et al. Identification and structure elucidation of epoxyjanthitrems from lolium perenne infected with the endophytic fungus Epichloë festucae var. lolii and determination of the tremorgenic and anti-insect activity of epoxyjanthitrem I. Toxins 2020, 12, 526. [CrossRef]

39. Cherewyk, J.E.; Parker, S.E.; Blakley, B.R.; Al-Dissi, A.N. Assessment of the vasoactive effects of the (S)-epimers of ergot alkaloids in vitro. J. Anim. Sci. 2020, 98, skaa203. [CrossRef] [PubMed]

40. Sharma, N.; Sharma, V.K.; Manikyam, H.K.; Krishna, A.B. Ergot alkaloids: A review on therapeutic applications. Eur. J. Med. Plants 2016, 14, 1-17. [CrossRef]

41. Rowan, D.D.; Dymock, J.J.; Brimble, M.A. Effect of fungal metabolite peramine and analogs on feeding and development of argentine stem weevil (Listronotus bonariensis). J. Chem. Ecol. 1990, 16, 1683-1695. [CrossRef] [PubMed]

42. Wilkinson, H.H.; Siegel, M.R.; Blankenship, J.D.; Mallory, A.C.; Bush, L.P.; Schardl, C.L. Contribution of fungal loline alkaloids to protection from aphids in a grass-endophyte mutualism. Mol. Plant-Microbe Interact. 2000, 13, 1027-1033. [CrossRef]

43. Schardl, C.L.; Grossman, R.B.; Nagabhyru, P.; Faulkner, J.R.; Mallik, U.P. Loline alkaloids: Currencies of mutualism. Phytochemistry 2007, 68, 980-996. [CrossRef] [PubMed]

44. Vassiliadis, S.; Elkins, A.C.; Reddy, P.; Guthridge, K.M.; Spangenberg, G.C.; Rochfort, S.J. A simple LC-MS method for the quantitation of alkaloids in endophyte-infected perennial ryegrass. Toxins 2019, 11, 649. [CrossRef] [PubMed]

45. Reed, K.; Nie, Z.; Walker, L.; Kearney, G. Fluctuations in the concentration of ergovaline and lolitrem B produced by the wild-type endophyte (Neotyphodium lolii) in perennial ryegrass (Lolium perenne) pasture. Anim. Prod. Sci. 2011, 51, 1098-1108. [CrossRef]

46. Fletcher, L.R.; Finch, S.C.; Sutherland, B.L.; deNicolo, G.; Mace, W.J.; van Koten, C.; Hume, D.E. The occurrence of ryegrass staggers and heat stress in sheep grazing ryegrass-endophyte associations with diverse alkaloid profiles. N. Z. Vet. J. 2017, 65, 232-241. [CrossRef] [PubMed]

47. Fuchs, B.; Krischke, M.; Mueller, M.J.; Krauss, J. Plant age and seasonal timing determine endophyte growth and alkaloid biosynthesis. Fungal Ecol. 2017, 29, 52-58. [CrossRef]

48. Vikuk, V.; Fuchs, B.; Krischke, M.; Mueller, M.J.; Rueb, S.; Krauss, J. Alkaloid concentrations of Lolium perenne infected with Epichloë festucae var. lolii with different detection methods-A re-evaluation of intoxication risk in Germany? J. Fungi 2020, 6, 177. [CrossRef] [PubMed]

49. Repussard, C.; Zbib, N.; Tardieu, D.; Guerre, P. Ergovaline and lolitrem B concentrations in perennial ryegrass in field culture in southern France: Distribution in the plant and impact of climatic factors. J. Agric. Food Chem. 2014, 62, 12707-12712. [CrossRef]

50. Ludlow, E.J.; Vassiliadis, S.; Ekanayake, P.N.; Hettiarachchige, I.K.; Reddy, P.; Sawbridge, T.I.; Rochfort, S.J.; Spangenberg, G.C.; Guthridge, K.M. Analysis of the indole diterpene gene cluster for biosynthesis of the epoxy-janthitrems in Epichloë endophytes. Microorganisms 2019, 7, 560. [CrossRef]

51. Wachowska, U. Susceptibility of cereals and other crops to Rhizoctonia cerealis. Phytopathol. Pol. 2000, $20,59-66$.

52. Burpee, L. Rhizoctonia cerealis causes yellow patch of turfgrasses. Plant Dis. 1980, 64, 1114-1116. [CrossRef]

53. Sneh, B.; Jabaji-Hare, S.; Neate, S.; Dijst, G. Rhizoctonia Species: Taxonomy, Molecular Biology, Ecology, Pathology and Disease Control, 2nd ed.; Springer Science \& Business Media, Kluwer: Dordrecht, The Netherlands, 1996.

54. Labruyere, R. Contamination of ryegrass seed with Drechslera species and its effect on disease incidence in the ensuing crop. Neth. J. Plant Pathol. 1977, 83, 205-215. [CrossRef] 
55. Hsiang, T. All you ever wanted to know about Fusarium patch/Microdochium patch/pink snow mold or whatever that disease is called. Green Master 2009, 44, 13-16.

56. Reddy, P.; Deseo, M.A.; Ezernieks, V.; Guthridge, K.; Spangenberg, G.; Rochfort, S. Toxic indole diterpenes from endophyteinfected perennial ryegrass Lolium perenne L.: Isolation and stability. Toxins 2019, 11, 16. [CrossRef] [PubMed]

57. Beloshapkina, O.O.; Katushova, M.S.; Kalashnikov, D.V. Improving methods for preventing diseases of pasture grasses and securing the quality of feedstuff. IOP Conf. Ser. Earth Environ. Sci. 2021, 624, 012150. [CrossRef]

58. Zhang, Y.-J.; Yu, J.-J.; Zhang, Y.-N.; Zhang, X.; Cheng, C.-J.; Wang, J.-X.; Hollomon, D.W.; Fan, P.-S.; Zhou, M.-G. Effect of carbendazim resistance on trichothecene production and aggressiveness of Fusarium graminearum. Mol. Plant-Microbe Interact. 2009, 22, 1143-1150. [CrossRef] [PubMed]

59. Marei, G.I.K.; Abdel Rasoul, M.A.; Abdelgaleil, S.A.M. Comparative antifungal activities and biochemical effects of monoterpenes on plant pathogenic fungi. Pestic. Biochem. Physiol. 2012, 103, 56-61. [CrossRef] 